\title{
The Conduit between Technological Change and Regulation
}

\author{
Marta Katarzyna Kolacz \& Alberto Quintavalla*
}

\begin{abstract}
This article discusses how the law has approached disparate socio-technological innovations over the centuries. Precisely, the primary concern of this paper is to investigate the timing of regulatory intervention. To do so, the article makes a selection of particular innovations connected with money, windmills and data storage devices, and analyses them from a historical perspective. The individual insights from the selected innovations should yield a more systematic view on regulation and technological innovations. The result is that technological changes may be less momentous, from a regulatory standpoint, than social changes.
\end{abstract}

\section{Introduction}

The capacity of regulation to respond to the legal issues presented by new technologies is not an unknown topic. While socio-technological innovations tend to open new possibilities once introduced, they might also challenge pre-existing regulatory paradigms. Throughout history, questions concerning the design of optimal regulation have repeatedly emerged in reaction to a radical transformation in society, which may be due to multiple factors such as morality and technology. The discussion on whether and how the law ${ }^{1}$ shall reflect these changes dates back over 2,000 years.

This introductory article to the present special issue of Erasmus Law Reviem ${ }^{2}$ intends to discuss hom the law has approached disparate socio-technological innovations over the centuries. The primary concern is to investigate the timing of regulatory responses. By doing so, we enter in the realm of regulation and technology, thus

* Marta Katarzyna Kołacz, Ph.D. Candidate in the Department of Private Law, Erasmus School of Law, Erasmus University Rotterdam, The Netherlands. Alberto Quintavalla, Ph.D. Candidate in the Rotterdam Institute of Law and Economics, Erasmus School of Law, Erasmus University Rotterdam, The Netherlands. The authors would like to thank Orlin Yalnazov and the two anonymous reviewers for their valuable comments as well as Luuk Hoogenboom for his excellent research assistance. The usual disclaimer applies.

1. With the term 'law', we refer to the law that exists at a specific point in time and that is implemented as such by courts or enforcement bodies.

2. The current special issue builds on the Erasmus Early-Career Scholars Conference, which was held from 11 April 2018 to 13 April 2018 at the Erasmus University, Rotterdam. Financial support received from the Erasmus Initiative 'Dynamics of Inclusive Prosperity', the Erasmus Trustfonds and the Erasmus Graduate School of Law is gratefully acknowledged. setting the conceptual framework for the other articles in the issue.

Legislatures and courts usually require a certain amount of time to handle the various challenges brought about by technology. This time period is necessary to acquire any relevant information about the legal issues posed by the new innovations. ${ }^{3}$ The length of time needed for this operation should depend on the risks and complexity of innovation. Yet, it seems that other factors are deemed more influential: it is commonly argued that the law responded in the past more slowly than it does at present. The printing press may serve as an illustrative example. It was invented in Europe around 1439. It allowed printed books to move across borders and started the era of mass communication. But despite its disruptive potential, it took a long time before responses to legal issues began to emerge. ${ }^{4}$ This was partly due to the slow pace of distribution and the difficulty of monetising the product.

In the twenty-first century, however, innovation and technological changes move at a much more rapid pace. Significant and impactful advances are secured almost daily as a consequence of digitalisation. In today's globalised world, innovations appear to follow each other not only in quick succession, but also on a larger scale than ever before. For example, WhatsApp killed the SMS revenues of the telecom sector within a single quarter. SMS itself had been a novel technology only a couple of years before its demise. Similarly, technologies such as blockchain, currently still in their infancy, are widely expected to disrupt long-established markets. Globalisation and digitalisation, in combination with technology, have created a new socio-technological context. The emergence of new technologies often launches

3. The article looks at the regulatory responses to technological change after the fact. The ex post view therefore coincides with the stages of innovation and diffusion. Academic research usually divides technological innovation into three stages: invention, innovation and diffusion. See e.g. J.A. Schumpeter, Theory of Economic Development (1934). Yet, legal scholars tend to perceive the stage of diffusion as different from technological innovation per se. See on this point e.g. N.A. Ashford, C. Ayres \& R.F. Stone, 'Using Regulation to Change the Market for Innovation', 9(2) Harvard Environmental Law Review 419 (1985). See infra Section 2.

4. One may think of the late establishment of copyright laws. With the exception of a (crude form of) copyright legislation by the Venetian State in Renaissance Italy, we had to wait until the enactment of the Statute of Anne in XVIII century. See B. W. Bugbee, Genesis of American Patent and Copyright Law (New York: Public Affairs Press) (1967), at 43-38; A. B. Birrell, Seven Lectures on the Law and History of Copyright in Books (London: Cassell) (1899), at 51-54; B. Kaplan, An Unhurried View of Copyright (New York: Columbia University Press) (1967). 


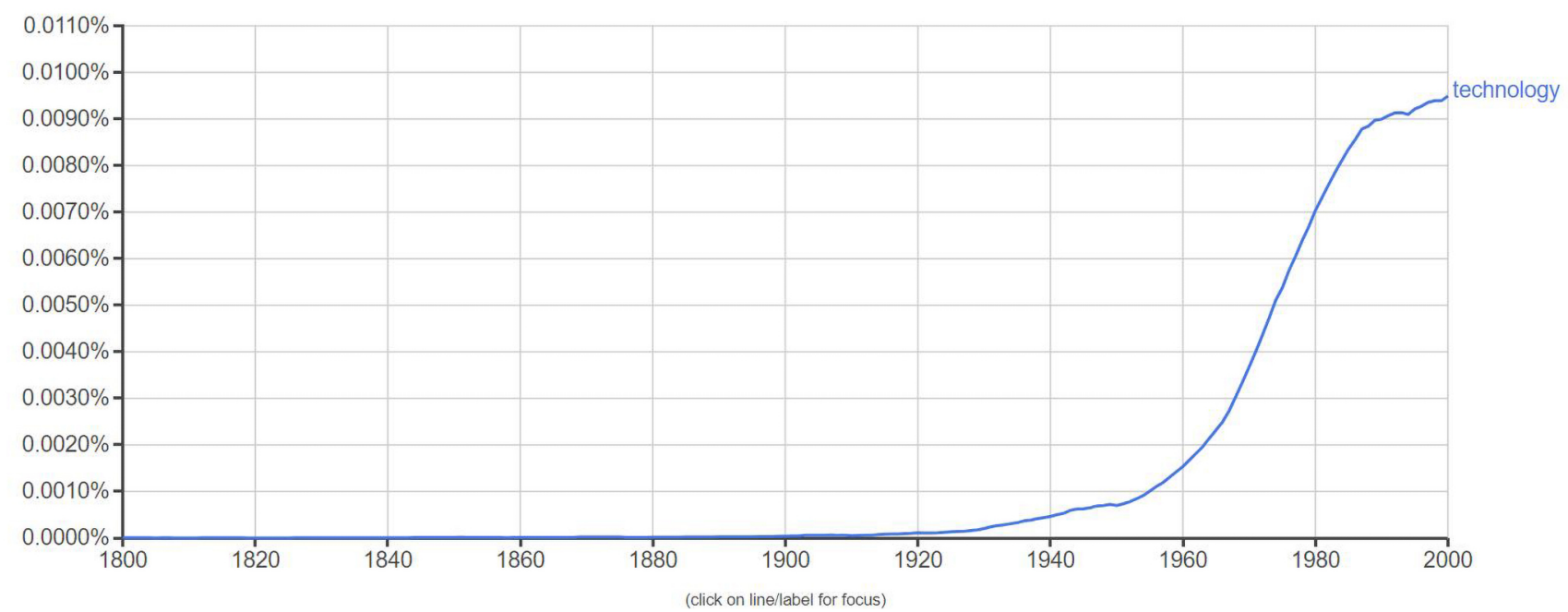

discussions on emerging legal (and moral) issues. For instance, the creation of new tools for Internet users, such as social networks, has brought out digitally expressed 'hate speech' and 'fake news' as well as many other collateral problems. Legislatures and courts are therefore called to tackle the legal issues at stake in a quick and orderly fashion. Besides, the cross-border aspect of current technological changes may exacerbate this problem. This has also been the case for Google and its search support when a U.S. District Court annulled (within the U.S. soil) a Canadian court's judgment that had directed the tech giant to stop displaying certain references to pirated products. ${ }^{5}$

Against this background, our contribution attempts to answer if law has approached socio-technological changes in a uniform manner. Put slightly differently, we consider if different types of socio-technological change may entail a different rate of regulatory intervention once the technology starts yielding negative externalities. To do so, the article circles on particular innovations connected with money, windmills and data storage devices and analyses them from a historical perspective. The individual insights from the selected innovations should yield a more systematic view on regulation and technological innovations.

The article is structured as follows. Section 2 advances the backbone proposition and theoretical approach of this article. We present technological changes as a part of social change, which has some distinctive problems. Section 3 analyses the development of regulations on particular technologies from a historical perspective.

5. See e.g. Goog/e v. Equustek Solutions Inc., 2017 SCC 34, [2017] 1 S.C.R. 824. In such a legal challenge, the technology company Equustek Solutions filed a lawsuit against Datalink Technology Gateways. The accusation was to sell products belonging to Equustek, thus misappropriating inter alia its trade secrets. Google was therefore required to remove Datalink websites from its search results, both in Canada and globally. Yet, the U.S. District Court for Northern California granted Google an injunction to prevent enforcement of the Canadian Court order in the U.S. territory. For the U.S. Direct Court's judgment see Google LLC v. Equustek Solutions Inc., 2017 WL 5000834 (N.D. Cal. Nov. 2, 2017).
While Section 4 develops some concluding observations in the context of regulating technologies, the last part (Section 5) provides an account of the (other) articles making up this special issue.

\section{Technology as a Facilitator of Social Change}

The term 'technology' has elicited a great deal of interest among scholars from disparate disciplines, such as philosophy, sociology and law. 'Technology', which is still a fuzzy concept, ${ }^{6}$ emerged not so long ago. Although the word entered the English language in the seventeenth century, its use became frequent and regular only in the early decades of the twentieth century. ${ }^{7}$ As proof to this, Figure 1 graphically displays how use of the word 'technology' only increased significantly in the 1930s. Similarly, the same word started appearing regularly in the EU parliamentary debates only in the last five years. ${ }^{8}$

The enmeshment of technology and law is thus quite recent. ${ }^{9}$ Debates in the sphere are commonly framed as some variant of the question 'how to regulate technolo-

6. There is no single definition of technology. For the purpose of this article and in line with previous literature, we employ the definition provided by Schon: 'any tool or technique, any product of process, any physical equipment or method of doing or making, by which human capability is extended'. See D. Schon, Technology and Change: The New Heraclitus (New York: Delacorte Press) (1967), at 1.

7. E. Schatzberg, 'Technik Comes to America. Changing Meanings of Technology before 1930', 47(3) Technology and Culture 486 (2006); L. Marx, 'Technology. The Emergence of a Hazardous Concept', 51(3) Technology and Culture 561 (2010).

8. The information is retrieved from www.europarl.europa.eu/plenary/en/ minutes.html\#sidesForm (last visited 28 January 2019). The search option allows looking for any word in the minutes of each plenary sitting of the European Parliament.

9. One may note that before 'technology' gained popularity, these discussions were couched in different terms - e.g. manufacturing, useful arts and invention. See Schatzberg, above n. 7. 
gy?'. ${ }^{10}$ Technology is regarded, in other words, as a rationale for regulation. As soon as a technological innovation takes place, it is expected that regulators should intervene to regulate it. Such a view may, however, fail to fully capture the meaning of technological change.

Technological changes enable people to broaden their usual field of action and, as such, may have different consequences for law and the organisation of society. ${ }^{11}$ For example, the invention of e-mail and the Internet offered the opportunity to communicate with other individuals over long distances and in real time. Yet, for regulation to be necessary, the use of e-mails must raise legal issues - salient for certain individuals in the society, which cannot be solved by established legal frameworks. ${ }^{12}$ From an ex post view, technology becomes a rationale for regulation only once it involves a societal disturbance. ${ }^{13}$

While technology offers individuals enhanced technical capabilities, it cannot determine historical outcomes by itself. Taking that view on technology leads us to perceive technological change as "one type of social change". ${ }^{14}$ Social change generally refers to the idea of a society moving forward by evolutionary means to secure people's interests in a multiplicity of forms. ${ }^{15}$ Social change can be driven by a wide array of forces, including inter alia behavioural changes or shifts in cultural beliefs. The Industrial Revolution and the feminist movement both exemplify this tendency.

It follows that technological change has some features that are distinct from those of social change. Technological change influences the course of social development. However, taken in isolation, it is not a reason to change the law. ${ }^{16}$ The social change brought about by technological developments might require a modification of the pre-existing legal framework. ${ }^{17}$ Technological changes are therefore less momentous, from a regulatory standpoint, than are social changes. Nevertheless, it seems that legislatures are sometimes urged to intervene solely because of the occurrence of technological change. For example, autonomous vehicles are not yet widespread but there are several attempts to regulate

10. R. Brownsword and K. Yeung, Regulating Technologies: Legal Futures Regulatory Frames and Technological Fixes (Opole: Hart) (2008).

11. Please see the definition provided at n. 6

12. Some legal issues that may arise vary from managing certain risks to protecting individuals' rights. Besides, we are not considering the 'regulatory capture' option.

13. W.E. Bijker and J. Law, Shaping Technology/Building Society: Studies in Sociotechnical Change (Cambridge: MIT Press) (1992), at 20-22. A societal disturbance can also result from the identification of potential undesirable consequences triggered by the technological change. That is to say, for a societal disturbance to exist, it is not necessary to have the actual occurrence of negative consequences.

14. L.B. Moses, 'Why Have a Theory of Law and Technological Change?', 8 Minnesota Journal of Law, Science \& Technology 589, at 598 (2007).

15. C.F. Sabel and J. Zeitlin, 'Historical Alternatives to Mass Production: Politics, Markets and Technology in 19th Century Industrialization', 108(1) Past and Present 133 (1985)

16. See Moses, above n. 14

17. L.B. Moses, 'Regulating in the Face of Sociotechnical Change', in R. Brownsword, E. Scotford \& K. Yeung (eds.), The Oxford Handbook of Law, Regulation, and Technology (OUP 2017), 573. them. ${ }^{18}$ Legal scholars have pinpointed a couple of reasons behind this tendency. First, technological change may occur faster than social change. The variation in rates of technological and social changes may generate a sense of unfamiliarity with the new technology, ultimately putting greater pressure for legal intervention. ${ }^{19}$ Secondly, the issues raised by technological changes are perceived as more objective - not tainted by any a priori ideological vision - and accordingly easier to regulate. ${ }^{20}$

However, the quest for a speedy regulatory response often results in disenchantment: it seems that law fails to keep pace with rapidly evolving technology. ${ }^{21}$ This narrative puts the time factor in the spotlight. Law, the argument runs, should be more effective and responsive in handling the challenges posed by technological innovations in anticipation of social change. In order to delve into this inquiry, one may ask whether law has approached various types of socio-technological changes in the same manner over the years. The ex post view we adopt forces us to consider the time period that coincides with the stages of innovation and diffusion of the technological change, thus excluding the ex-ante feardriven legislation. ${ }^{22}$ If this analysis shows a heterogeneity in the rate of regulatory responses, it becomes necessary to identify what particular socio-technological changes should be addressed first. Based on these assumptions, the following section intends to examine the regulatory responses to selected innovations.

18. For example on the civil liability for damages caused by robots, including autonomous cars, see e.g. Report with recommendations to the Commission on Civil Law Rules on Robotics, European Parliament Committee on Legal Affairs (2017), 6-8, 12, 16-18, available at: www. europarl.europa.eu/sides/getDoc.do?pubRef=-//EP//NONSGML +REPORT+A8-2017-0005+0+DOC+PDF+V0//EN (last visited 28 January 2019); on the product liability regarding the vehicles and its software, see e.g. State of Michigan Bill Number SB 663 (2013).

19. See Moses, above n. 14, at 600 .

20. L. Lessing, 'Understanding Changed Readings: Fidelity and Theory', 47 Stanford Law Review 395, at 400 (1995); M.E. Price and J.F. Duffy, 'Technological Change and Doctrinal Persistence: Telecommunications Reform in Congress and the Court', 97 Columbia Law Review 976, at 1008-1009 (1997); M.E. Price, 'The Newness of New Technology', 22 Cardozo Law Review 1885 (2001).

21. L.B. Moses, 'Recurring Dilemmas: the Law's Race to Keep Up with Technological Change', 8(2) University of Illinois Journal of Law, Technology and Policy 239, at 247 (2007); G.E. Marchant, 'The Growing Gap between Emerging Technologies and the Law', in G.E. Marchant, B.R. Allenby \& J.R. Herkert (eds.), The Growing Gap between Emerging Technologies and Legal-Ethical Oversight. The Pacing Problem (Berlin: Springer) (2011) 19, at 20.

22. The fear-driven legislation develops particularly in the first stage of a technological change. See on this point e.g. P. Kleve, 'Technology Law: Symbolic Solutions to Problems, or Solutions to Symbolic Problems?', in P. Kleve and C. van Noortwijk (eds.), Something Bigger Than YourselfEssays in Honour of Richard De Mulder (Rotterdam: Erasmus School of Law) (2011), at 131-5. 


\section{Historical Instances of Particular Innovations}

\subsection{Preliminary Remarks}

There is a virtually endless list of historical instances when socio-technological change has prompted regulatory responses. Selecting representative responses is a tall order. To begin with, we do need particular innovations that have triggered regulatory responses by the legislatures and courts, both in the past and in the present. For the purpose of this article, we focus on money, windmills and data storage devices.

These rubrics were selected for several reasons. Technology is an integral part of all of them: windmills and data storage devices are technological innovations per se, whereas money has been significantly affected by developing technologies over time. Contemporary electronic money can even be considered a pure technology, in the same mould as windmills and data storage devices. In addition, the selection of the three subjects allows us to consider regulatory responses from a fairly wide spectrum of legal fields, ranging from private law to administrative law. Specifically, monetary technology triggered the development of commercial laws (as well as laws of financial systems). Windmills prompted changes in administrative and environmental law. Lastly, data storage devices touch upon civil and consumer law. ${ }^{23}$

We do not, however, aim to provide an exhaustive list of all the regulatory responses that have occurred within the three rubrics. Our examples instead show facets of legal responses resulting from or triggered by technological developments. Since law responds to socio-technological change in a way that impinges upon disparate interests, it is important to confine ourselves to a fairly limited set of regulatory patterns. The selected examples in which regulation approaches the legal issues posed by new technologies will serve as a point of reference for further research.

\subsection{Money}

Before proceeding to the analysis of its specific regulatory responses, a definition of money shall be provided. According to Ferguson, money is

a medium of exchange which has the advantage of eliminating inefficiencies of barter, a unit of account, which facilitates valuation and calculation; and a store of value, which allows economic transactions to be concluded over long periods as well as geographical distances. ${ }^{24}$

23. One may also note that some of the selected rubrics, and namely money and data storage devices, relate to the other articles in this issue. The importance of historical framing helps to observe and understand the techno-legal debates of the past and present, their developments and directions.

24. N. Ferguson, The Ascent of Money. A Financial History of the World (London: Penguin Press) (2009), at 24.
The physical object that symbolises money has changed over the centuries. Coins circulated in the Ancient Mediterranean world. ${ }^{25}$ However, coins cannot be considered the only precursors of today's money. While clay tokens were popular a long time ago in ancient Mesopotamia, banknotes have been in circulation since the seventh century. ${ }^{26}$ The twentieth century triggered the development of an electronic store of monetary value, known as e-money. More recently still, cryptocurrencies such as Bitcoins entered the 'market'. ${ }^{27}$ These developments triggered regulatory responses, and it is on those facets of regulation that we focus here.

Regulation has traditionally focused on remedying asymmetries of information that pertain to standards of value. Such an approach was common since the early medieval times. For instance, several penal laws from that time advert to compensation payments in precious metals for the commission of various felonies. ${ }^{28}$ In addition, regulations about coins often included technical requirements - that is, type, shape and weight - as well as the methods of production. The 1580 Mint Ordinance of the Polish King Stefan Batory is a striking example. This authoritative decree specified all the necessary requirements for the production of coins, as well as the type, stamp, weight of metals, ranks of craftsmen and systems of contracting between the Crown and local mints. ${ }^{29}$ Setting these technical requirements can be seen as one response to emerging legal problems, such as the unification of governance systems on the Polish and Lithuanian lands as well as tax payments. It also facilitated local and international trade because the standardised monetary value increased certainty in transactions and prevented the activities of profiteers working against the interests of local traders.

Similarly, the modern coinage system operates by designating specific objects as money. As a consequence, those objects acquire a specific value. ${ }^{30}$ The designation process thus happens through regulation. Regulation identifies certain means of payment that can serve as money. Bringing as an example the current monetary system of Poland, the relevant regulation states that $z l o-$ ty and grosz, which are operating in coins and banknotes, are the currency signs of the Republic of Poland. ${ }^{31}$ The National Bank of Poland, on the basis of further implementing provisions, issues banknotes and coins according to certain technical requirements. Similarly, Poland regulates electronic money, which can be

25. G. Davies, History of Money: From Ancient Times to the Present Day (Cardiff: University of Wales Press) (2002), at 74-78.

26. Ferguson, above n. 24, at 28.

27. Cryptocurrencies reflect an encrypted value, existing not as a paper money or coins but as strings of digital code. For more see A.M. Antonopoulos, Mastering Bitcoin: Unlocking Digital Cryptocurrencies (Newton: O'Reilly) (2004).

28. P. Grierson, The Origins of Money (London: Athlone Press) (1977), at 12-19.

29. S. Tymieniecki, Zarysy do dziejów mennic koronnych Zygmunta III. W szesnastym wieku (Drukarnia Czas) (1917), at 3-10.

30. L. Kurke, Coins, Bodies, Games, and Gold. The Politics of Meaning in Archaic Greece (Princeton: Princeton University Press) (1999), at 305.

31. Art. 31 Ustawa z dnia 29 sierpnia 1997 r. o Narodowym Banku Polskim Dz.U.2017.0.1373 t.j. 
considered an equivalent of money. ${ }^{32}$ In parallel to the traditional means of payment, cryptocurrencies began to grow in popularity in 2009. The major issues posed by cryptocurrencies are the effective functioning (and strength) of centralised currencies and the illegitimate activities surrounding decentralised currency, such as money laundering, terrorist financing and tax evasion. ${ }^{33}$ States are therefore urged to address these raising legal issues, which became popular because of the widespread use of cryptocurrencies in the society. In line with this approach, the Polish government has, for example, adopted regulations whereby a virtual currency is deemed a digital representation of value and not legal tender. ${ }^{34}$

Closely linked to money as a means of exchange is the regulation of standards for securities preventing forgeries. From a historical perspective, these standards already developed in ancient Rome where, in the third century BCE, coins were produced with serrated edges. For the same purpose, China introduced a concession for brass and established state printing-houses using specific colour printing, rich designs and official stamps in the Middle Ages. ${ }^{35}$ Similar solutions can be found in Europe: under the aforementioned Polish Mint Ordinance, coins were exclusively produced in contracted mints. Each mint had its assayer responsible for the supervision of a production process and the maintenance of the quality of coins. Assayers were personally liable for any failure to observe the regulations. ${ }^{36}$

In modern times, banknote security printing started when, in the end of the eighteenth century, the Netherlands began using in-house designs and engravings for music types. ${ }^{37}$ This and further technological developments such as colour printing, 3D devices, watermarks and holograms have led regulators to introduce technological standards. In the Eurozone, the European Central Bank and National Central Banks are the only agencies responsible for the issue of currencies. More specifically, they are entitled to introduce new series of euro banknotes with standardised security features, thus benefiting from advances in banknote technology. ${ }^{38}$ The intertwinement of fiat currencies, technology and law

32. Ustawa z dnia 19 sierpnia 2011 r. o usługach płatniczych Dz.U. $2011 \mathrm{Nr}$ 199 poz. 1175 t.j.

33. For more see R. Houben and A. Snyers, 'Cryptocurrencies and Blockchain: Legal Context and Implications for Financial Crime, Money Laundering and Tax Evasion' - European Parliament Study Requested by the TAX3 committee (2018), available at: www.europarl.europa.eu/ cmsdata/150761/TAX3\%20Study\%20on\%20cryptocurrencies\%20and \%20blockchain.pdf (last visited 6 December 2018).

34. Art. 1(26) Ustawa z dnia 1 marca 2018 r. o przeciwdziałaniu praniu pieniędzy oraz finansowaniu terroryzmu Dz.U. 2018 poz. 723 t.j.

35. M. Zajęcki, 'Regulacje prawne dotyczące monet i pieniądza papierowego w dawnych Chinach', in P. Wilinski, O. Krajniak \& B. Guzik (eds.), Prawo wobec wyzwań współczesności. Tom IV (Poznan) (2007), at 233.

36. Tymieniecki, above n. 29, at 52-54

37. K.J. Schell, 'History of Document Security', in K. De Leeuw and J. Bergstra (eds.), The History of Information Security (London: Elsevier) (2007), at 203-4.

38. Decision of the European Central Bank of 19 April 2013 on the denominations, specifications, reproduction, exchange and withdrawal of euro banknotes (recast) (ECB/2013/10) (2013/211/EU) L 118/37. facilitates the safety of the transactions by providing a regulatory response to the developments occurred in technology.

It can be seen from this sketch that monetary regulation has grown hand in hand with technological and social changes, both in the past and in the present. Regulation - which can encompass both the development of new rules and the adaptation of the existing ones - comes into play as soon as new objects or means of payment are widely accepted into circulation. In this way, the law recognises the growing usage of different means of payment, institutionalising them by setting regulatory frames such as the ones on issuance and turnover. In that sense, regulation seems an outcome based on actual results (effective social change) rather than a simple forecast (the occurrence of a technological change).

\subsection{Windmills}

The harnessing of wind power is a technology that has started developing in eastern Persia thousands of years ago. ${ }^{39}$ These primitive wind devices were then followed by (vertical) windmills on the Dutch and Mediterranean territories in the fourteenth century. ${ }^{40}$ At that time, the primary function of these windmills was to pump water, mill grain, and drain land. ${ }^{41}$ In the nineteenth century, the high rate of technological progress spurred the development of new turbines, a new type of windmills. Both windmills and wind turbines have been rather popular in certain areas of the globe. Nevertheless, their use caused environmental disturbances that have required a regulatory response. It seems therefore appropriate to look a little more closely at the development of the corresponding legal frameworks.

Windmills are inherently embedded in the landscape of the Netherlands. ${ }^{42}$ Windmills equipped with water-lifting technology have been integrated in the Dutch drainage system since the fifteenth century. ${ }^{43}$ In other words, windmills were one of the effective tools to combat against demanding environmental conditions and continuous threat of floods. Thus, although the construction of these drainage windmills was rather costly for an ordinary farmer, ${ }^{44}$ windmills spread around all the areas affected by poor drainage.

39. R.W. Righter, Wind Energy in America: A History (Norman: University of Oklahoma Press) (1996), at 7. Here, we refer to horizontal windmills. For more about the construction of the first mill devices see R.L. Hills, Power from Wind (Cambridge: Cambridge University Press) (1994), at 11-17.

40. J.K. Kaldellis and D. Zafirakis, 'The Wind Energy (R)evolution: A Short Review of a Long History', 26 Renewable Energy 1887, at 1887 (2011).

41. For more see Hills, n. 39, at 115-236.

42. M. Reuss, 'Learning from the Dutch: Technology, Management, and Water Resources Development', 43(3) Technology and Culture 465, at 466 (2002).

43. A. Kaijser, 'System Building from Below: Institutional Change in Dutch Water Control Systems', 43(3) Technology and Culture 521, at 530 (2002). Besides, consider that a large part of the Dutch territory is potentially threatened by flooding.

44. J. de Vries, The Dutch Rural Economy in the Golden Age, 1500-1700 (New Haven: Yale University Press) (1974), at 198. In order to facilitate the construction of windmills, a framework for financing, building and operating windmills was also devised. For more see Kaijser, above n. 43, at 536 . 
However, the large number of windmills built had a detrimental impact on the water balance at a regional level. ${ }^{45}$ More specifically, windmills were lifting an excessive amount of water into the so-called boezem. ${ }^{46} \mathrm{By}$ doing so, there was an actual danger that the surrounding farmlands would be flooded. A 1444 decree of the water authority of Delfland exacerbated this problem because it stipulated that drainage windmills would operate whenever there was sufficient wind. ${ }^{47}$ This situation led to legal disputes concerning the appropriate water level in the boezem. ${ }^{48}$ The debate was particularly lively between 'highlanders' and 'lowlanders' due to their differing interests vis-à-vis the water levels. ${ }^{49}$ As a result, the regional water authorities decided to intervene from both technical and legal standpoints. With regard to the former, they increased the capacity of sluices. ${ }^{50}$ As to the latter, the regional water authorities started issuing windmill permits, thus assuming more power and responsibilities. ${ }^{51}$ In line with this new approach, a 1562 decree of the Delfland water authority set a fixed water level in the boezem. ${ }^{52}$

The modern usage of windmills' descendants - wind turbines - is aimed at the production and supply of energy. Popularised in the nineteenth century, wind turbines have become a common mean of producing energy in the twentieth century. ${ }^{53}$ Wind turbines, like drainage windmills, can influence the neighbourhood

45. Kaijser, above n. 43, at 536 .

46. The boezem is an area in which excess water can be stored before it is permanently discharged onto a river that brings the water to the sea.

47. Het hoogheemraadschap van Delfland, Het oudste keurboekje, at 55.

48. P.J.E.M. van Dam, Vissen in veenmeren: De aalvisserij bij de sluizen tussen Haarlem en Amsterdam en de ecologische transformatie in Rijnland 1440-1530 (Hilversum: Uitgeverij Verloren) (1998), at 82-86.

49. C. Postma, Het hoogheemradschap van Delfland in de middeleeuwen, 1289-1589 (Hilversum: Uitgeverij Verloren) (1989), at 372-5; D. van Doorn, Gedenkschrift uitgegeven ter gelegenheid van het 700-jarige bestaan van het Hoogheemraadschap van Schieland (Uitgever: De Boer-Cuperus) (1994), at 62-65.

50. For the readers who are not very familiar with hydraulic engineering and water management, a sluice is a passage for water usually controlled by a gate. For more about the improvements of sluices see P.J.E.M. van Dam, 'Ecological Challenges, Technological Innovations. The Modernization of Sluice Building in Holland, 1300-1600', 43(3) Technology and Culture 500 (2002)

51. Kaijser, above n. 43 , at 538

52. Postma, above n. 49, at 378-83. A similar approach can be found in other regions of Europe such as some territories currently belonging to Poland. That is because of the Mennonites who were prosecuted and forced to leave their home territories. In the sixteenth century, Mennonites settled in the region called Żuławy Wiślane - the delta area of Vistula River. There, they implemented irrigation systems including polders and windmills. Operation and maintenance of polders was within the competence of the so-called embankment unions. These were established to protect the region against floods. Their growing importance as far as flood protection was concerned resulted in several decrees institutionalising their operations. For example, the King of Prussia Wilhem II issued a decree giving a statue to the Embankment Union of Vistula and Nogat ('Związek Wałowy Wisły i Nogatu') in 1889. It contained detailed regulations, such as technical maintenance parameters regarding water level in the Vistula River. For more see K. Cebulak, Detla Wisły powyżej i poniżej poziomu morza (Nowy Dwor Gdanski: Stowarzyszenie Żuławy i Lokalna Grupa Działania Żuławy i Mierzeja) (2010).

53. S. Mathew, Wind Energy Fundamentals, Resource Analysis and Economics (Berlin: Springer) (2006), at 4-6. both positively and negatively. In fact, these turbines are not only an energy source but also a cause of potential disturbances.

The Netherlands launched a large-scale programme for the development of wind turbines in the 1970s. ${ }^{54}$ Although these policies were also promoted to enhance renewable energy deployment, local planning for wind farms ${ }^{55}$ revealed to be problematic. ${ }^{56}$ Specifically, locals tend to view wind farms with hostility due to environmental concerns, especially noise. Accordingly, it appeared that certain (social) standards had to be set in order to ensure acceptable noise levels. Dutch authorities began adopting environmental regulations for wind turbines a few years after the inception of the programme. The most recent standards indicate that the noise caused by wind turbines should be restricted to a maximum of $47 \mathrm{~dB}$ Lden and $41 \mathrm{~dB}$ Lnight at any noise-sensitive location. ${ }^{57}$

In both the Middle Ages and the 1970s, regulatory responses were not contemporaneous to technological change. More precisely, regulation aimed at responding to environmental disturbances of windmills and wind turbines resulted only after the use of the technological development became widespread. The technology per se was insufficient to trigger regulatory intervention. As in the case of money, regulation emerged because of issues raised by the widespread use of windmills (social change) rather than by the creation itself (technological change).

\subsection{Data Storage Devices}

The collection and aggregation of information has always driven improvements in social welfare. Collecting data has yielded evidence of historical events, as well as the discovery of the origins of certain customs and practices. Data were originally passed on through storytelling, songs and dances, which were also testimonies of local culture and belief. As time passed, writing and storage technologies have vastly expanded our society's ability to store and disseminate information. This has been recognised to serve various state's and societal needs, especially in the era of digitisation. Nevertheless, the related risks have not escaped regulators' attention. Collecting and storing data for public purposes has been common practice for centuries. Public registers, in particular, have been an integral part of state organisation. ${ }^{58}$ Public registers served the political system. Cadasters were kept for taxation purposes. One of the oldest examples dates to ancient Rome. Registers with data

54. L.M. Kamp, R.E.H.M. Smits and C.D. Andriesse, 'Notions on Learning Applied to Wind Turbine Development in the Netherlands and Denmark', 32 Energy Policy 1625, at 1628 (2004).

55. Wind farm consists of an area with a group of wind turbines.

56. S. Breukers and M. Wolsink, 'Wind Energy Policies in the Netherlands: Institutional Capacity-building for Ecological Modernisation', 16(1) Environmental Politics 92, at 101-102 (2007).

57. Besluit wijziging milieuregels windturbines (14 oktober 2010).

58. Registers used for collections of taxes were already known to the civilizations of Mesopotamia, Assyria, Babylon and Egypt. For more see A. Hopfer and W. Wilkowski, 'Kataster nieruchomości w Polsce - jest czy go nie ma?', 79(1) Przegląd Geodezyiny 6, at 6 (2007). 
- which were collected manually - were used to produce an inventory of lands and people. Accordingly, the population was classified into different social classes depending on income level. ${ }^{59}$ In August's period, all the citizens were required to declare size and types of crops, as well as property income. The unified capitastrum (known then as catastrum) became the basis for taxation. $^{60}$

The use of inventories for public purposes continued into the Middle Ages. An efficient collection of public receivables required the use of increasingly formalised registers. These registers reflected the various fiscal burdens on citizens. The use of registers made it possible to prevent fraud and enhance enforcement. In Poland, registers indicated tax obligations imposed by the King on particular states. ${ }^{61}$ The owners were obliged to pay levies, both regular and extra regular. ${ }^{62}$ In the fifteenth and sixteenth century, the extraordinary land tax (poradlne) was calculated on the basis of the register from $1578 .{ }^{63}$ Registers were carried out also when the Crown was acquiring new territories. ${ }^{64}$ For example, in 1650, a special register (abiurata) was issued. It indicated the number of declared land possessions belonging to the population of Smolensk, which had been annexed from the Russian Empire in the Time of Troubles.

A special regulation concerning registers per se started only in the eighteenth and nineteenth centuries. Poland, after the collapse of the Polish-Lithuanian Commonwealth, was divided between three countries, these being Habsburg Austria, the Kingdom of Prussia, and the Russian Empire. Each of these countries has started to implement their administration on the occupied territories. For example, the Kingdom of Prussia established a fixed register of land and real estate taxes in an 1867 act. This was followed by a land register ordinance aiming at the further standardisation of registers in $1872 .{ }^{65}$

In the past, the main purpose of registers had been to itemise lands and people in order to bring benefits to the state. Modern registers serve different functions. Past

59. For more see W. Suder, Census populi. Demografia starożytnego Rzymu (Wrocław: Wydawnictwo Uniwersytetu Wrocławskiego) (2003).

60. A. Zachariasz, 'Odczytywanie historii zapisanej w krajobrazie', 5(8) Roczniki Geomatyki 45 (2007).

61. Similarly as the case of Dutch water management that was presented in the preceding section, registers and special maps were prepared for a better administration of dikes and polders. Registers and maps were the basis for taxation assessment of people who were supposed to bear the costs of their maintenance. For the better preparation of maps, different regions started to put more formal obligations on surveyors. They were obliged to increase the level of competence and achieve a status of a sworn surveyor. For more see R.J.P. Kain and E. Baigent, The Cadastral Map in the Service of the State: A History of Property Mapping (Chicago: University of Chicago Press) (1992), at 9-24.

62. The most famous ones were: the land tax imposed in the fourteenth century by the King Kazimierz Wielki ('poradlne' - as of the sixteenth century change for 'łanowe') or the seventeenth century family tax ('podymne').

63. A. Gomułowicz and J. Małecki, Podatki i prawo podatkowe (New York: Lexis Nexis) (2006), Chapter XVIII section 1.2

64. A. Rachuba (ed.), Metryka Litewska Rejestry podymnego Wielkiego Księstwa Litweskiego. Województwo Smoleńskie 1650 r. (Warsaw: DiG Instytut Historii PAN) (2009).

65. M. Mika, 'Historia Katastru Polskiego', 6 Infrastruktura i Ekologia Systemów Wiejskich 75, at 78-80 (2010). research considers digitisation as the main driver of change. ${ }^{66}$ The state has recognised the benefits of technology by explicitly regulating the various electronic procedures that may be relevant for its citizens. An example may be Article 61(3a) of the Polish Code of Administrative Procedure. ${ }^{67}$ Similarly, Article 14 indicates that public authorities in charge of public registers that use ICT systems must meet the minimum criteria established for any ICT system. ${ }^{68}$ It is therefore possible to observe that the use of regulation is primarily aimed at meeting the needs of private citizens.

Data storage devices have developed considerably in the last centuries. However, regulation was only introduced when social conditions began to change. Again, technology per se was not sufficient to trigger any regulatory action. Conversely, the combination of technological change and social factors contributed to the development of new data storage regulation.

\section{Concluding Remarks}

The previous section considered historical responses of legal systems to changes in technology and, ultimately, society. It showed that competent institutions have employed different regulatory means for dealing with technological changes. However, a common pattern can be identified: legal intervention often follows social change. It seems that legislatures will not offer regulatory responses in every instance of technological change after the fact. For the expense of regulation to be justified, it is necessary for technological change to trigger social change, and further that the pre-existing legal framework cannot accommodate the social change.

There is thus no correspondence between the rate of technological change and the intensity of regulatory responses. On one hand, it is possible for new innovations to be distributed around the globe in hasty fashion due to globalisation and the advantages of modern-day life. On the other hand, governments and courts often struggle to provide speedy legal responses. Adapting old legal structures to new situations is sometimes insufficient. For regulation to be effective, some time must lapse between the innovation and the resultant change in social organisation. Then regulators have two main choices. Firstly, they can steer the evolution of rules

66. As described by Fred Cate, digital information is easier to generate, manipulate, transmit and store. Costs connected with these operations are lowered. Additionally, generation or storing of information triggers generation of additional digital information because of operating parameters of computer systems (e.g. through back-up copies). See F.H. Cate, Privacy in the Information Age (Washington: Brookings Institution Press) (1997), at 14-15.

67. Ustawa z dnia 14 czerwca 1960 r. Kodeks postępowania administracyjnego Dz.U. $1960 \mathrm{nr} 30$ poz. 168 t.j. The article was included in the novelization of the code in 2010 . This article indicates that the date of initiation of proceedings at the request of the party, which is brought electronically, coincides with the day when the request is entered into the ICT system of the public administration authority.

68. Ustawa z dnia 17 lutego 2005 r. o informatyzacji działalności podmiotów realizujących zadania publiczne Dz.U. 2005 nr 64 poz. 565 t.j. 
alongside the development of technologies. This would allow the adaptation of the existing legal rules to new legal problems - this being the case of adapting the rules to changing features of money and public registers. Secondly, the regulator can devise new rules responding to new characteristics of technologies and related legal questions - this being the case of administrative rules regarding the usage of early windmills.

\section{The Special Issue}

This introductory article has started discussing how regulatory responses may not immediately follow the technological change after the fact. We did not aim to provide any definitive answer to that question. The intention was to instead present technological change as a part of social change. The current article has not, however, discussed any substantive regulatory efforts. That is the task that each of the articles in this issue takes up. More precisely, these articles will isolate specific issues raised by technology and compare them vis-à-vis existing regulatory frameworks. This type of operation requires a keen eye as well as employing, if needed, innovative approaches. In fact, regulatory adaptation may also necessitate from traditional forms of regulation. ${ }^{69}$ The further articles of this special issue purport to do so.

The special issue consists of (another) four articles discussing legal approaches to socio-technological changes. These socio-technological changes are broadly connected with digitisation and the operation of the Internet. Some of the phenomena that are discussed in those articles are not new. However, digitisation has caused them to acquire new meanings and cause new problems. In all the remaining four contributions, the authors consider how law could or should approach socio-technological changes.

The article of Katharina Kaesling discusses enforcement mechanisms in social networks. The author tackles the well-known problem of hate speech and defamation and presents it in a new context involving a technological change. A technological change refers here to online social networks (e.g. Facebook) where hate speech or defamation can 'go viral'. As a result, the uncontrollable distribution goes beyond the control of the statement creator. Kaesling notices that this also goes beyond the capabilities of public policy makers. Accordingly, they need to rely on private entities.

Staying in the field of humans' online outputs, but turning more to the previously discussed data storage, the articles of Alessandro El Khoury and Joanna Mazur bring the problem of personal data and the right to information regarding automated decision-making solutions using personal data. Both articles contribute to describing social changes connected with people moving in the online reality and thus losing their anonymity. In this regard, the articles are based on the analysis of certain aspects of General Data Protection Regulation (GDPR). El Khoury discusses the binary notion of personal data and highlights its limitations in the GDPR. Mazur, on the other hand, brings limitations of GDPR by focusing on privacy protection in regard to the right to explanation. Like Kaesling, both authors highlight the contingent inability of public policy makers to draft timely, effective legal responses to socio-technological changes.

While the previous articles aim at analysing the situation of an individual in digital reality, Morshed Mannan brings in some aspects of worker cooperatives becoming a part of the digitised world. Mannan explores how organisational innovations can draw from blockchain projects and potentially facilitate the growth of worker cooperatives. The article of Mannan, similarly to the previous three, indicates the necessity of a continuous assessment of innovations, which cannot be detached from the context in which they occur. In other words, a proper understanding of the new technology would allow to better address the emerging legal issues. 